\title{
Geo-Resources Recycling as the Way of Mining Wastes Disposing
}

\author{
Asmelash Abay, ${ }^{1, *}$, Mabel Imbuga ${ }^{2}$, Chandara Malik ${ }^{3}$, Kumar Singh $^{3}$, and Dmitriy Borodin ${ }^{4}$ \\ ${ }^{1}$ College of Natural and Computational Sciences, Department of Earth Science, Mekelle University, \\ P.O.Box.3066, Mekelle, Ethiopia \\ ${ }^{2}$ Jomo Kenyatta University of Agriculture \& Technology, Mining, Materials \& Petroleum \\ Engineering Department, P.O. Box 62000 - 00200, Nairobi, Kenya \\ ${ }^{3}$ Indian Institute of Technology, Mining Engineering Department, 110016 Hauz Khas, New Delhi, \\ India \\ ${ }^{4}$ T.F. Gorbachev Kuzbass State Technical University, Surveying and Geology Department, 650000 \\ Vesennya st. 28, Kemerovo, Russian Federation
}

\begin{abstract}
Scientific and technological progress envisages the solving the most important problems in the main areas of mineral processing, leading to the perfection of technological processes, improving quality indicators and reducing the cost of production. Rational use of minerals at the stages of their extraction and enrichment is a single indivisible problem, the main task of which is the fullest use of basic and rare minerals. Geo-resources include mineral deposits and subsurface materials (solid, liquid, gaseous, mixtures), underground space (cavity), subsurface energy (static, geo-dynamic, geomagnetic). Geo-resources are provisionally recognized as geoinformation, characterized by various attributes and properties of subsurface material (minerals, overburden, etc.), and the other geo-resources, including streams migrating into the depths (fluids, magma, etc.). It is clear that mineral resources are part of the subsurface material. Therefore, the most important aspect of geo-resources development today is the initiation of recycling of their industrial processing.
\end{abstract}

\section{Introduction}

The existing technology of extraction and enrichment of minerals leads to the fact that only a small component becomes a useful part. The rest is enclosing and overburden rocks $\approx 70 \%$ of the volume of the minerals in the array. For example, in the coal industry, only $20 \%$ of the mined material is coal, the rest goes to the dumps, and only $4 \%$ is recycled. Such dumps occupy millions of hectares of land and negatively affect the environment.

Dumps of surface and ubderground development of minerals are a valuable raw material for the production of a number of materials (mainly building materials). They contain a different kind of clay, stone and sand materials, chalk and other components. Especially valuable are the dumps of the enrichment enterprises of a number of industries.

\footnotetext{
* Corresponding author: asmelashby@yahoo.com
} 
In concentrating factories of non-ferrous metallurgy with dump tailings, all iron contained in ore is lost, as well as significant amounts of sulfur, oxidized metal compounds, a number of rare and dispersed elements.

Currently, both types of waste (overburden heaps and tailings of enrichment) are used slightly. The experience of industrial production shows that wastes of mining and mineral processing serve as raw materials for the production of fillers of porous concretes, building bricks and ceramics, plaster and masonry solutions, crushed stone and other building materials.

Recycling is the industrial process of waste return into the cycle "production - consumption". But it is necessary to avoid confusing recycling with the waste recovery. The term "recovery" has a special meaning: it refers to the process of returning the waste into the techno-genesis. In other words, the waste recovery is a process, and waste recycling is an activity consisting of different kinds of waste processing which comprises a number of different processes. In this sense, the recycling is one of the waste recovering elements, which in turn is part of the waste development. Recycling of waste is carried out by re-use of waste for the same purpose. For example, we are already used to the glass bottles recycling after they are appropriate for the safe handling and marking (labeling), or by returning the city waste after appropriate processing into the production cycle (e.g. recovered paper - into the manufacture of paper etc.). 2]:

Cyclical use of the geo-resource is determined by the following terms and conditions [1-

1. The variety of material composition.

2. The climatic seasons.

3. The safety of mineral deposit development.

4. The specificity of mining and processing technology.

\section{Used methods}

Some authors propose mining and technological wastes to be divided into two groups: balance ones are wastes of production and consumption, the use of which is economically expedient at the existing level of technology development and technology of their processing; off-balance - waste production and consumption, the use of which is economically impractical, but in the future they may be involved in the production process [3-5].

Utilization of minerals from technogenic deposits is effective. However, this requires an in-depth study of the quality of waste, its compliance with state industry standards and technical conditions. New technologies are needed for the recovery of waste and the production of products from them. When implementing waste management projects, costs are usually bought up for 1.5-2 years.

Determination of the degree of suitability of industrial wastes of enterprises and industries as secondary mineral resources may be established as a result of their study by geological methods, including geochemical, mineralogical, petrographic, structural, lithological and other. These methods should be integrated with hydrogeological, engineering-geological, physical-mechanical study of waste. Industrial waste must be studied with a wide involvement of a modern complex of technological tests for enrichment, pyrometallurgical and hydrometallurgical remaking [6-7].

To develop the methodology of recycling and disposal of mineral resources production geo-resources the following steps are required:

The first step is classifying the resources involved in coal mining and the resulting waste.

The second step is identifying the potential of recycling and disposal of each geo-resource. 
The third step is developing the guidelines and boundary conditions for the coal waste recycling and disposal.

The fourth step is identifying the opportunities and suggesting the methods of coal waste recycling and disposal.

The final fifth step is the forming and embedding technology for coal waste industrial recycling and disposal as the geo-resource.

At the coal extracting enterprises we have the following elements of the recycling system:

1. The quarry water recycling for production needs by cyclic purifying from grains and chemical elements using artificial filtering arrays of overburden. The overburden rocks on open coal pits can be used to clean the quarry water by making special artificial systems including filter arrays, dams and settling ponds. These installations can work cyclically with seasonal, objective (exhausted filter array is replaced by the following one), manufacturing (when mining moved to the other segment of quarry field, the water treatment system moves to the same direction, and then everything comes back to the previous side).

2. Quarry water recycling for production needs by periodic purifying in the settling ponds.

3. Clay overburden utilization i the pore space of dumped rock. Such geo-resource as underground space can be used for this purpose. The cyclic character of this process is defined by seasonal, technological factors. At the same time there is a recycling of waste water in the system "hydro-mechanized cut - the dump" [8].

4. The topsoil recycling for reclamation of the earth surface disturbed by open pit mining.

5. The utilization of the quarry overburden rock for the upgrading of the landscape area near the quarry fields (filling in uneven terrains).

6. The utilization of the quarry overburden rock for installing the bases for engineering constructions, roads, power lines, railway roads.

7. The recycling of the ground waters pumped through the drain holes and transmitted to the coal enterprise's constructions for industrial needs.

\section{Results and discussion}

Every geo-resource has a great capacity to satisfy human needs. However, in the process of coal mining by the open pits, some resources receive an additional potential which is manmade, and opens up new possibilities of using this resource. These additional technogenic potential s determined by the appearance of the new qualities and properties of geo-resource.

The geo-resource's technogenic potential may be low, medium, high, which determines the perspective of its use by coal enterprises.

Maternal substance of subsurface resources is represented rock and semi rock being destroyed and converted into a lumpy condition by excavator or explosion acquires the property of porosity. The porosity and a large internal surface of the new rock open up the additional possibilities of using technogenic arrays generated from this rock. These possibilities include interior placement of another substance, recycling of quarry and mine water by filtration. As unit capacity of quarry mining and transport equipment tends to grow, the porosity and pore sizes of the dumps increase, raising technological potential of pilling arrays.

In the scheme of rational complex use of mineral raw materials, the following independent trends are singled out: geological-mineralogical, mining, concentrating, chemical-metallurgical, economic and ecological:

1. Geological and mineralogical direction includes the following sections: a comprehensive study of mining areas and deposits; regularities in the placement of mineralization, minerals and coals; material composition of ores and coals; separation of technological types of ores, technological mapping of deposits; poor and off-balance ores; geological and mineralogical study of man-made raw materials; study of overburden and enclosing rocks; technological geochemistry and mineralogy. 
2. The mining sector includes the following sections: development and implementation of optimal mining systems; secondary development of site-births; rational use of mineral raw materials with the organization of selective extraction; underground leaching of metals; the creation of a quality management service for raw materials. The right choice of the development system ensures a productive, economically profitable and safe operation of the deposit with rational use of mineral resources.

3. The main components of the enrichment direction are: the introduction of technological schemes for ore enrichment, providing high technical and economic indicators and increasing the extraction of metals; enrichment of refractory and off-balance ores; development of schemes for extracting metals from technogenic products.

4. The main sections of the chemical and metallurgical sector are: the introduction of optimal schemes of chemical and metallurgical processing; extraction of impurity elements; the use of hydrometallurgy for unenriched ores; use of process dusts and gases; heap leaching of metals. The most important issue related to the problem of the rational use of mineral raw materials is the involvement of secondary raw materials in the cycle of metallurgical production. This makes it possible to economize on the use of natural ore resources, to obtain metals with simpler and cheaper metallurgical methods, and to further increase the output of metal products. In perspective, secondary raw materials should become the main source of obtaining some metals.

5. Organization of production and economy. This direction includes the following sections: development of a methodology for determining the socio-economic efficiency of mineral raw materials; organization of low-waste mining and processing of ores; Development of an economic mechanism for the efficient use of minerals. The economy of mineral raw materials and its assessment are the most important complex issues covering the scale of reserves and industrial-geological conditions of mineral deposits, analysis of their development, extraction and processing.

Geological and economic assessment is carried out at all stages of exploration of deposits. At the search stage, it allows to discard non-industrial ore occurrences and deposits, and from the rest choose the most promising for preliminary exploration. Geological and economic assessment includes the following operations: justification of the conditions, delineation in accordance with the deposit.

Economic evaluation of mineral deposits determines the national-economic effect of the use of their reserves, taking into account the time factor. Its main indicator is determined in the form of the difference between the value of the final output and the costs of obtaining it.

The most important indicators of the economic evaluation of deposits during their development are losses and dilution of mineral resources; complex use of raw materials; conditioning conditions for mineral raw materials; the organization of the quality management of the extracted raw materials.

The problem of rational integrated use of mineral raw materials, along with its directions, should be considered taking into account environmental conditions. Therefore, the issues of environmental protection, development of deposits, technological processing of minerals should be considered in a single complex.

Along the way, extractable host rocks during the development of mineral deposits are widely used in the national economy. They are used in construction industry, metallurgy, light and food industries, as chemical, ceramic and agronomic raw materials, and also as a possible source for extraction of metals, minerals and other useful components. Particularly diverse applications are found in the manufacture of various building materials.

Overburden and enclosing rocks in their geological features and use in the national economy are divided into the following five groups: rocky, clastic, clayey, carbonate and feldspar.

Sand-gravel rocks with the inclusion of pebble and boulder are widely distributed and occupy the largest volumes in dumps of overburden, formed during the development of ore, 
nonmetallic, coal and especially placer deposits. Their classification is based on the granulometric composition, according to which the size of the fractions increases from 0.05 to 700 $\mathrm{mm}$ and more, the following rock types are distinguished: sands, gravel, pebbles, boulders. They consist of fragments of various rocks or minerals and fill more fine-grained matter (heterogeneous, uniformly grained), mineral composition, and strength and degree of roundness.

Gravel is used both in natural form and after crushing fractions and is used in the form of a large aggregate of concrete and in the construction of iron and motor roads.

Sands are used in the construction of railways and roads, as a small aggregate in the manufacture of concrete, for the manufacture of mortars, in the production of silicate building materials, the removal of clay in the manufacture of rough ceramics, the production of roofing roll materials, the laying of underground mining workings, land reclamation open mining of minerals. Also, sands are used as a glass raw material, molding material in foundry, abrasive material, for the production of refractory bricks (dinas), the production of fine ceramics, water filtration, and the metallurgical industry.

Carbonate rocks, represented by limestones, chalk, dolomites, magnesites, siderites, rhodochrosites and some others, are quite widespread in nature and constitute about $20 \%$ of the volume of all sedimentary rocks of the earth's crust. Their main varieties are limestones, $\mathrm{ml}$ dolomites and magnesites

Depending on the physical and mechanical properties, carbonate rocks are used in construction as wall, butovite and facing stones, paving stones, drafts, rubble. They are used in metallurgical, cement, chemical, food, cellulose-paper, glass, electrical, perfume industries, as well as in agriculture for liming acidic soils and additives for cattle and birds.

For the production of cement, limestones and chalk are used, consisting of calcite, the main component of raw batch. Carbonate raw materials used for glass production - limestone, chalk and dolomite. The purest kind of calcium raw material is chalk, which is used in cooking the best varieties of glass. Limestones and dolomite limestones are used to produce lime, which is the main constituent of mortars, as well as in the chemical industry in the production of soda, calcium carbide, bleach, caustic potassium and sodium, and soda ash.

In the metallurgical industry, carbonate rocks are widely used for the production of refractories and are used as fluxes. Limestone is used in the processing of nepheline rocks for alumina, and 5-7 tons of limestone is needed to produce 1 ton of alumina. Limestone serves as fluxes in non-ferrous metallurgy: for smelting copper, antimony and tin, as well as during the processing of oxide-silicate nickel ores.

Technical and economic issues of recycling are the most important when planning the development of deposits. They can be successfully solved with such minimum industrial contents that ensure cost-effective processing of technogenic waste. The economic benefit from developing them can be provided in two cases: a sharp increase in the cost of extracted components and the use of a fundamentally new highly efficient technology for processing technogenic raw materials.

The most important factor for increasing profitability in the development of deposits is the integrated use of mineral raw materials with the extraction of basic and associated metals, as well as obtaining the most important materials for use in industry and construction.

Technogenic wastes are often highly mixed rocks of clay -sandy-grained composition, which can not be directly used for manufacturing important materials for industry. Considering the huge reserves of non-fractionated material and the poor development of the issues of their technological development, special research is needed to find substitutes for traditional materials and to obtain new types of them that can be widely used in the national economy.

Wastes from concentrator factories, which are a fine-grained, homogeneous material, from which it is possible to extract different metals, and also to obtain quartz, quartz-feldspar, 
feldspathic, mica, alumina and other concentrates. Even more valuable for use in the industry waste chemical and metallurgical production and thermal power plants.

\section{Conclusion}

To date, huge amounts of man-made waste have been accumulated in the extraction and processing of minerals, the use of which in the national economy can bring great economic benefits and is important for solving environmental problems. Among them, overburden and enclosing rocks are distinguished; dump tailings and slimes of concentrating mills; slags, dust and gases of metallurgical plants; gold-slag waste from the combustion of coals. The special features of natural and technogenic geo-resources determine its potential possibilities of storage, processing, disposal or recycling after adequate using. The greatest value for humanity belongs to the recycling technologies, providing the ability to use geo-resources several times in the manufacturing with minimal additional cost. The next in value are the geo-resource's wastes disposal technologies which address to additional production tasks, changing the direction of use. The processes of recovering and recycling have the most technological potential and provide coal production with more of safety and environmental protection.

\section{References}

1. H. Pavolová, S. Khouri, M. Cehlár, L. Domaracká, M. Puzder, Metalurgija, 55:4, 712714 (2016)

2. M. Prekopová, J. Janočko, V. Budinský, M. Friedmannová, Environmental Earth Sciences, 76:1, 25 (2017)

3. V. Gogolin, Y. Lesin, A. Djagileva, E3S Web of Conferences, 15, 01001 (2017)

4. S.N. D'yakov, A.V. Papin, A.V. Nevedrov, E.V. Zhbyr', Coke and Chemistry, 55:10, 363 (2012)

5. Kvasova, B. Gerike, E. Murko, D. Skudarnov, E3S Web of Conferences 21, 03016 (2017)

6. T. Gvozdkova, M. Tyulenev, S. Zhironkin, V. A. Trifonov, Yu. M. Osipov, IOP Conference Series: Earth and Environmental Science, 50:1, 012010 (2017)

7. V.A. Gogolin, Yu.A. Ryzhkov, Soviet Mining Science, 13:1, 17-20 (1977)

8. T. Gvozdkova, S. Markov, N. Demirel, S. Anyona, E3S Web of Conferences 21, 01024 (2017) 